\title{
DRD2 NM_000795.3:c.957C>T
}

National Cancer Institute

\section{Source}

National Cancer Institute. DRD2 NM 000795.3:C.957C>T. NCI Thesaurus. Code

C126837.

A nucleotide substitution at position 957 of the coding sequence of the DRD2 gene where cytosine has been mutated to thymine. 